\title{
VERŐCE - POWRÓT DO WĘGIERSKIEGO OKRESU W ŻYCIU STANISŁAWA VINCENZA
}

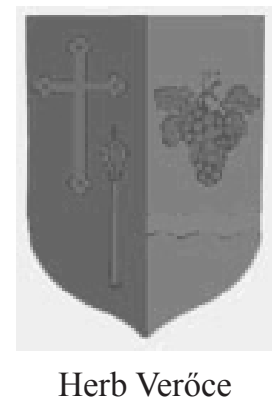

Życie Stanisława Vincenza - ,gawędziarza z Karpat Wschodnich”, „myśliciela spod Czarnohory”, „Homera Huculszczyzny”, jak nazywali go jemu współcześni - toczyło się w różnych epokach i różnych miejscach dziewiętnastowiecznej i dwudziestowiecznej Europy, niezwykle ważnych, jak się wydaje, dla kulturowego kształtu starego kontynentu.

Wzrastanie, dojrzewanie i wiek męski, czyli lata 1888-1939, zbiegły Vincenzowi na południowo-wschodnich kresach Rzeczypospolitej (m.in. we Lwowie), w Wiedniu i Warszawie; lata wojny 1939-1945 w Królestwie Węgier; lata 1946-1971 - na emigracji we Francji i Szwajcarii. Biografię Vincenza wypełniły z jednej strony swoiste trudne doświadczenia pisarza, z drugiej zaś w wielkiej obfitości zdarzenia typowe dla losów Europejczyków jego czasów. Ponadto, co tak często podkreślają badacze Vincenzowego dzieła, sam pisarz przenosił się, wręcz podróżował myślami do tej Europy, która już przeminęła, ale na szczęście pozostawiła bogate dziedzictwo - do Europy grec- 
kich pasterzy i ateńskich intelektualistów oraz rzymskich myślicieli, do Europy Dantego, Szekspira, Goethego i polskich romantyków. Europejskość bowiem oznaczała dla Vincenza swoistą syntezę myśli ludzkiej i korespondencję sztuk. Nie da się zrozumieć losu człowieka, ani poznać jego idei bez wniknięcia w przestrzeń, w której przychodzi mu żyć, poznawać, zgłębiać tajemnice bytu i trwania. Dał temu wyraz w dziele największym, nie skończonym - tetralogii Na wysokiej połoninie, która, jak słusznie zauważa biograf Vincenza, jest „,poszukiwaniem wzoru społeczności ludzkiej"1.

Obcowanie z tekstami Vincenza jest pielgrzymowaniem do źródła, jest wędrówką do naszej europejskiej samoświadomości i naszego bycia tu i teraz. Europa jego wyobrażeń jest jedna i nie można jej dzielić na wschodnią, centralną i zachodnią lub południową i północną. Należy ją w miarę możliwości ogarniać całą w jej wymiarach historycznym i współczesnym. Celem intelektualnych wędrówek po płajach i dolinach europejskiego losu, na które zabiera nas niestrudzony „piewca kresowej arkadii”, jest bowiem ,przyszły człowiek, by poznał wiedzę o życiu”. Sam Vincenz w liście do jednego z przyjaciół napisał: „Moja epika miała być wyrazem tego, co wiecznie «dzieje się» w górach"3.

Aby zrozumieć sytuację Vincenza, postanowiłem choć na chwilę wejść w węgierską przestrzeń jego życiowych doświadczeń; chciałem zobaczyć to, co on widzial, i w dzisiejszej rzeczywistości odszukać to, co mogło być ważne dla jego sposobu odbierania i interpretowania świata. Pojechałem więc w sierpniu 2008 r. na Węgry. Okres węgierski w biografii pisarza spod Czarnohory jest szczególny i chyba najbardziej tajemniczy - tam wszak znalazł schronienie dla siebie i rodziny, tam tworzył, uczył się języka, tłumaczył i w końcu przeszedł swój czas próby...

Na Węgrzech Vincenz był dwukrotnie. Najpierw, po wkroczeniu do Polski Armii Czerwonej 17 września 1939 r., wraz ze starszym synem

\footnotetext{
1 Mirosława Ołdakowska-Kuflowa, Stanisław Vincenz wobec dziedzictwa kultury, Lublin 1997, s. 52.

2 Tamże, s. 116.

3 List Vincenza do Lajosa Áprilyego z czerwca 1943 r., w: Stanisław Vincenz, Atlantyda. Pisma rozproszone z lat II wojny światowej, wybór, wstęp i opracowanie Jerzy Snopek, Warszawa 1994, s. 123.
} 
Staśkiem pisarz dokonał rekonesansu. W Budapeszcie starał się zalegalizować swój pobyt, a przede wszystkim otrzymać wizy wjazdowe do neutralnej Szwajcarii. Prawdopodobnie prosił o jakąś pomoc swojego przedwojennego przyjaciela Hansa Zbindena oraz Jerzego Stempowskiego, który towarzyszył Vincenzom w przekraczaniu zielonej granicy polsko-węgierskiej. W październiku pisarz wrócił do domu i został aresztowany przez NKWD ${ }^{4}$. Po opuszczeniu aresztu podjął intensywne przygotowania do ucieczki z okupowanego kraju.

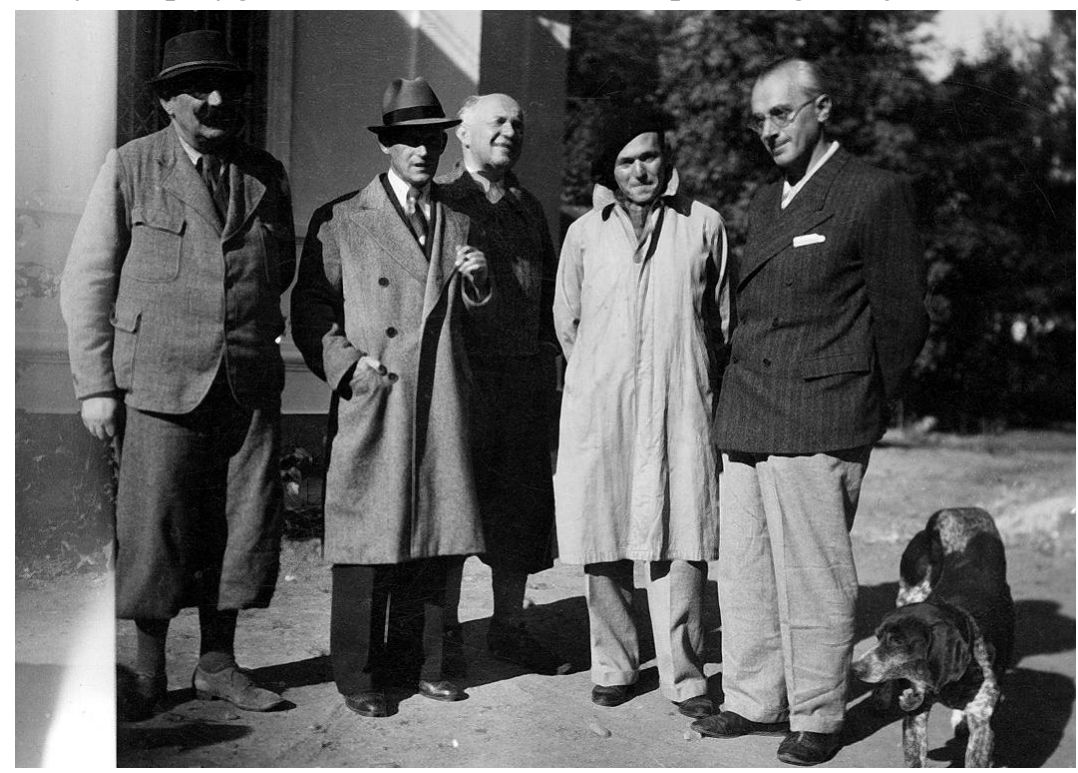

„Październik 1939 r., pierwszy pobyt Ojca na Wegrzech, zanim wrócił po nas do Bystreca, 20 października. Zdjęcie z Nagy Gejece, gdzie Ojciec i starszy brat się schronili u rodziny państwa Kendych. Od lewej: pan Kendy, pan Miłobędzki (oficer Wojska Polskiego), Stanisław Vincenz, Stanisław Aleksander Vincenz (starszy syn Vincenza, który z nim przeszedł na Węgry i tam został przez całą wojnę), Jerzy Stempowski, któremu udało się opuścić Węgry i pojechać do Szwajcarii, zanim granice zostały zamknięte" - podpis Barbary Wanders-Vincenz.

4 Swoje perypetie z administracją sowiecką autor opisał w Dialogach z sowietami, Londyn 1966. 
W marcu 1940 r. w drogę powrotną na Węgry udali się synowie pisarza, Stanisław i Andrzej, a on sam i reszta rodziny dwa miesiące później ${ }^{5}$. Zarówno w 1939 r., jak też pod koniec maja 1940 czasowego schronienia udzieliła Vincenzom węgierska, ziemiańska rodzina Kendych. Według Barbary Wanders-Vincenz, córki pisarza, majątek Kendych znajdował się w miejscowości Nagy Gejece ${ }^{6}$ („Cichy dwór. Wino i winogrona"7).

Później na pewien czas Vincenzowie wyjechali do obozu dla uchodźców cywilnych w Leányfalu nad Dunajem (miejscowości sławnej ze źródeł termalnych). Zdzisław Antoniewicz wspominał:

Koło Szentendre, w pięknej okolicy był obóz cywilny w Leányfalu, łatwo osiagalny z Budapesztu kolejką elektryczną. Tam Antall ${ }^{8}$ ulokował wybitniejszych uchodźców, naukowców, artystów [przebywał tam znany tenor Witold Łuczyński - T. M.], działaczy społecznych i politycznych ${ }^{9}$.

Obóz liczył około 200 mieszkańców i w sposób szczególny interesował się nim wywiad niemiecki.

Jesienią 1940 r. rodzina Stanisława Vincenza przyjechała do Budapesztu (zamieszkali w Budzie, w dzielnicy na wzgórzu Sváb-hegy), gdzie nawiązała kontakt z inżynierem Martinem Hajdu, który do września 1938 r. zajmował się w Galicji głębokimi odwiertami naftowymi, m.in. reprezentując amerykański koncern Ingersoll Rand Company; prawdopodobnie miał również związek z firmami nafciarskimi samego Vincenza i jego krewnych. Państwo Erna i Martin Hajdu zaopiekowali się rodziną pisarza do czasu, gdy Komitet Obywatelski ds. Pomocy Uchodźcom Polskim na Węgrzech z siedzibą w Peszcie przy ul. Garibaldiego 3 (w czasie wojny nosiła nazwę Géza utca), przyznał 210.

Mirosława Ołdakowska-Kuflowa, Stanisław Vincenz. Biografia, Lublin 2006, s. 208-

${ }^{6}$ Część informacji przytaczanych w artykule otrzymałem bezpośrednio w listach od Barbary Wanders-Vincenz, mieszkającej w Lozannie, oraz od Joanny i Andrzeja de Vincenzów, mieszkających w Heidelbergu.

7 Stanisław Vincenz, Outopos. Zapiski z lat 1938-1944, Wrocław 1993, s. 75.

8 Dr Jozef Antall był dyrektorem IX Departamentu Spraw Socjalnych węierskiego MSW.

9 Zdzisław Antoniewicz, Rozbitkowie na Wegrzech. Wspomnienia z lat 1939-1946, Warszawa 1987, s. 175. 
Vincenzom na wynajem mały, pożydowski domek w miejscowości Nógrádverőce. Mieszkali tam z przerwami do marca 1946 r. Ponadto „uchodźcy otrzymywali [...] na wyżywienie i inne wydatki zapomogę w wysokości 60 pengo miesięcznie"10. Była ona kilka razy podnoszona zarówno dla internowanych żołnierzy, jak i uchodźców cywilnych.

\section{Verőce}

Drugą część Dialogów z Sowietami Vincenz rozpoczyna od krótkiego opisu miejsca swojego pobytu na Węgrzech:

Od kilku lat mieszkaliśmy na Węgrzech, jakie 40 kilometrów na zachód od Budapesztu, w ustronnej wsi, na lewym brzegu Dunaju, z pretensjami miasteczka, nawet letniska. Okolica, gdzie Dunaj w kilku potężnych skrętach przebija się przez góry bramami skalnymi, a potem tworząc sporą wyspę piaszczystą rozdziela się na dwa potężne ramiona. W tak heroicznej walce rzeka wytworzyła tam krajobraz idylliczny, jakich niewiele. Współżycie osiedli, lasów, sadów owocowych i cichych dopływów, figura nadziei dla skołatanych wojnami rozbitków. Tymczasem te pagórki, jary, lasy i skrytki z natury rzeczy były świetnym terenem dla wojny i stały się nim niebawem ${ }^{11}$.

Trzeba przyznać, że polski pisarz dość surowo potraktował wieś Verőce, która zasługiwała i wtedy, i obecnie na więcej uwagi zarówno historyków, jak i podróżników. Pierwsze ślady osadnictwa w tym miejscu datowane są na epokę brązu, ale już w III wieku naszej ery Rzymianie wybudowali w tym miejscu most przeprawowy, którego archeologiczne ślady zachowały się do dziś. W korespondencji króla Beli IV z 1244 r. wspomina się o ludności naddunajskiej osady Veröce. Z kolei Ludwik I Wielki (1342-1382) zbudował tam dla swojej córki Hedvigi letnią rezydencję, w XV wieku zaś król Maciej Korwin wybudował zamek. Za panowania Turków miasteczko Verőce, jak

\footnotetext{
$10 \quad$ Tamże, s. 37.

11 Stanisław Vincenz, Dialogi z sowietami, Londyn 1966, s. 183. Autor podaje błędnie kierunek geograficzny, gdyż Verőce znajduje się na północ, a nie na zachód od Budapesztu.
} 
i reszta kraju, podupadło. Ponowny rozkwit nastapił za czasów monarchii austro-węgierskiej w połowie XIX wieku. W 1850 r. Verőce połączono linią kolejową z pobliskim miastem biskupim Vác i Budapesztem. Osiem lat później założono w nim pierwszą linię telegraficzną i urząd pocztowy. W XX wieku, w związku z rozwojem metropolii budapesztańskiej, Verőce stało się miejscem wypoczynku i natchnienia dla elity intelektualnej i artystycznej ówczesnych Węgier. Zaczęło odgrywać taką rolę, jak Nałęczów czy Zakopane w Polsce przełomu wieków. Powstały tam wille i pensjonaty znakomitych architektów (np. willa Miklósa Ybla), zbudowano baseny kapielowe i przystań dla statków parowych, przywożących letników ze stolicy, pobliskiego Wyszehradu i Esztergomu. Wakacje zaczęli tu spędzać tacy pisarze i poeci jak Endre Ady (1877-1919), Zsigmond Móricz (1879-1942), Frigyes Karinthy (1887-1938), aktor Huszár Pufi i kompozytor Béla Bartók (1881-1945). Chwały miejscowości przydał także tworzący w niej rzeźbiarz i twórca ceramiki artystycznej Géza Gorka (18941971). W 1945 r. Gorka powrócił z emigracji i osiadł w Verőce - możliwe, że Vincenz miał okazję go tam poznać. Obecnie miasteczko liczy 2700 mieszkańców.

Kiedy wraz z przyjaciółmi przyjechałem do Verőce 9 sierpnia 2008 r. wczesnym popołudniem padał deszcz, a na wzgórzach wyszehradzkich kładły się gęste mgły. Pierwsze kroki skierowałem na ul. Szamos. Tam pod numerem 32-34

mieszkał (młody wówczas) Polak, Paweł Kowalinski, żonaty z Węgierką [nauczycielką - T. M.]. Miał liczne kontakty z Rodzicami, po wojnie zajmował się odesłaniem ich książek do Francji. Jego korespondencja z Rodzicami jest złożona w Ossolineum we Wrocławiu. Nie potrafię powiedzieć czy Kowalinski jeszcze żyje, ale węgierska rodzina powinna tam być

- napisała mi w liście pani Barbara Wanders-Vincenz. Pod wskazanym adresem nikogo nie zastałem, ale sąsiedzi potwierdzili, że „Kowalski" (tak mówili o Kowalinskim) tu mieszkał, a obecnie dom należy do jego córki, Marii, która akurat gdzieś wyjechała. Zostawiłem 
w bramie wizytówkę. Jeden z sąsiadów zagadnął mnie po angielsku. Na dźwięk nazwiska Vincenz sięgnął po telefon. Z dłuższej rozmowy po węgiersku mogłem wychwycić nieustannie powtarzane nazwisko naszego pisarza. Po chwili poinformował mnie, żebym pospacerował po miasteczku i około 17 czekał pod domem-muzeum, w którym tworzył Géza Gorka, niedaleko torów kolejowych, na mężczyznę z białą brodą. Ruszyłem więc na spacer.

Przede wszystkim poszedłem do pobliskiego kościoła na wzgórzu, zbudowanego w stylu barokowym w latach 1736-1743. To tu Stanisław Vincenz przychodził na niedzielną sumę (,gdy moim zwyczajem przyszedłem na sumę z opóźnieniem, musiałem stanąć przy samych drzwiach w tłumie"12 - wspominał). Roztaczał się stamtąd widok na miasteczko, zabudowane w większości parterowymi domkami, i Zakole Dunaju. Po drugiej stronie rzeki ciągnęły się zielone wzgórza i wtedy zrozumiałem, dlaczego, mimo doświadczeń wojennych, Vincenz mógł czuć się tutaj całkiem dobrze. Wszystko, co tu widział, co go otaczało i czego doświadczał w czasie licznych spacerów, musiało mu przypominać rodzinne strony, do których miał już nigdy nie powrócić. Koło kościoła spotkałem kilku starszych ludzi - pytałem ich o Vincenza (miałem na kartce specjalnie napisany tekst po węgiersku). Niestety, kręcili przecząco głowami. Pytałem także, czy pamiętają polskich oficerów - w czasie wojny w Verőce był obóz dla internowanych. Podobne odpowiedzi. A przecież przebywali tutaj oficerowie i żołnierze polscy, funkcjonariusze Korpusu Ochrony Pogranicza i Policji Państwowej oraz wielu cywili. Mieszkali głównie na kwaterach u węgierskich gospodarzy.

Patrzyłem na panoramę miasteczka, a zaczęło się wypogadzać i przebijające się przez chmury słońce ukazywało je w nowym świetle, i zastanawiałem się nad tym, czym w istocie było przez sześć lat to miejsce dla Vincenza? Biorąc pod uwage jego dorobek pisarski, aktywność publiczną i działalność pomocową, można zaryzykować tezę, że była to dla niego kraina wytchnienia, spełnienia i co najważniejsze próby dla jego człowieczeństwa.

12 Tamże, s. 244. 
Veröce było miejscem wytchnienia, bo to właśnie tu, w czarującym, naddunajskim krajobrazie, obserwując spokojną toń szerokiej rzeki, w której każdego dnia przeglądały się masywne i dumne mury wyszehradzkiego zamczyska, autor Prawdy starowieku, oddalony od traumatycznych doświadczeń okupacji niemieckiej i sowieckiej w Polsce, mógł z dystansu spojrzeć na swój dorobek pisarski i intelektualny, zebrać nowe siły i uwierzyć w sens pisania dalszych części połonińskiej tetralogii i innych ważnych dla Europy (jej samookreślenia) tekstów ${ }^{13}$. Należy wspomnieć takie utwory jak: Mickiewicz a Dante (1941), Walt Whitman - poeta Ameryki (1941), Atlantyda (1941), O ksiażkach i czytaniu (1942), Brama do Wegier (1943), Hamlet jako czytelnik (1945), fragmenty Barwinkowego wianka, przekład Timajosa Platona i wierszy Lajosa Áprilyego (1887-1967). Dodajmy, że z tym ostatnim Vincenz zaprzyjaźnił się na początku 1943 r. i odwiedzał go po drugiej stronie Dunaju w wiosce Szentgyörgypuszta, położonej tuż koło Wyszehradu.

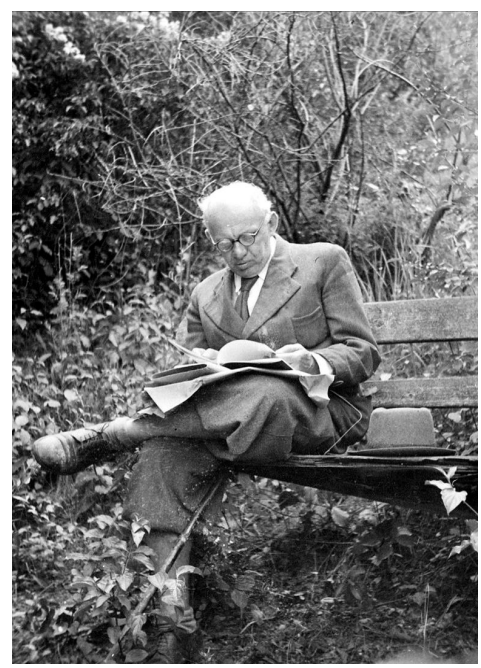

Verőce, $1942 \mathrm{r}$.

13 Przepiękne opisy naddunajskiej przyrody, otaczającej Veröce - a szczególnie ciekawe obserwacje ptactwa - znajdujemy w Outoposie, dz. cyt., s. 156-158 i 171-172. 
Verőce było miejscem spełnienia, bo to właśnie tu (i w Budapeszcie) Vincenza traktowano jako niezwykłą osobowość i depozytariusza ważnych, humanistycznych prawd. Odkrył w sobie zdolności translatorskie (nie bez wpływu Kazimiery Iłłakowiczówny) i nawiązał ważny dialog ze środowiskiem artystycznym Węgier (esej Pole Bobrowe z 1943 r. zadedykował pisarce Lili Wagner-Veszi $\left.{ }^{14}\right)$. Tu także odwiedzali go węgierscy, polscy i szwajcarscy przyjaciele - przede wszystkim Marina i Hans Zbindenowie w czerwcu (maju?) 1942 r.

Verőce stało się w końcu dla Vincenza miejscem egzaminu moralnego - szczególnie po wkroczeniu Niemców (w marcu) i niedługo potem Armii Czerwonej (w grudniu) na Węgry w 1944 r. Pisarz udzielał schronienia i wszelkiej możliwej pomocy potrzebującym. Czynił to już wielokrotnie wcześniej, ale terror niemiecki (,Tymczasem Niemcy wyłapywali również Polaków gdzie mogli, aresztowali także mego syna" ${ }^{15}$; „W tym samym czasie bowiem Niemcy polowali po miastach i miasteczkach na naszych rodaków i na resztki poukrywanych po kątach Żydów"16) i sowiecki zmusiły go do zupełnie nowego typu działalności publicznej. Autor Na wysokiej połoninie wspominat:

...ze wszystkich stron wsi przybiegali znajomi i nieznajomi Węgrzy z prośbami o różne interwencje. $Z$ początku o ukrywanie lub ratowanie kobiet, nieraz o jakieś pertraktacje co do kwatery, rekwizycji lub rabunku i później już o napisanie lub przeczytanie czegoś po rosyjsku [...]. Zresztą nie inaczej postępowali inni Polacy zamieszkali w tejże wsi, w szczególności inżynier G. [prawdopodobnie Gadomski - T. M.], a także polski żołnierz K., z zawodu mechanik [prawdopodobnie chodzi o Pawła Kowalinskiego - T. M.]. Pośredniczyli między gminą a okupantami, niejednokrotnie nie mieli czasu na spanie. A prawdę mówiąc inżynier G. kilkakrotnie narażał swe życie. Ale ostatecznie byli młodsi ode mnie, a koniec końców wciagał się do pomocy każdy kto mógł, bo było wielu potrzebujących $^{17}$.

14 Prof. Csaba G. Kiss ustalił, że pisarka wyemigrowała z Węgier do Anglii w 1948 r. W tym roku prof. Kiss odwiedził miasto Hódmezővásárhely w poszukiwaniu śladów Vincenza. Tam właśnie w czerwcu 1943 r. powstał esej Pole Bobrowe.

15 Stanisław Vincenz, Dialogi... dz. cyt., s. 184.

16 Tamże, s. 185.

17 Tamże, s. 189. 
Sam niewiele mając, jako wojenny rozbitek, który wszystko pozostawił za pasmem Czarnohory, Stanisław Vincenz dzielił się, czym tylko mógł. Był w tym wspierany przez pierwszą (Lenę) i drugą żonę (Irenę) i wspólnie z całą polską kolonią w Verőce (chodzi o kilkunastu, może kilkudziesięciu polskich żołnierzy i oficerów internowanych tam w 1939 r.) zdawali egzamin ze swego człowieczeństwa. W Polu Bobrowym odnalazłem cytat, który bardzo dobrze oddaje osobistą sytuację samego autora:

Czasem dopiero pewien nieoczekiwany, jak gdyby nawet błahy, powód wysuwa na dominujący plan cechy, których dotąd nie zauważono. W dziejach niejeden przykład dałby się znaleźć. Za taki przykład uważają biografowie Sokratesa rok 399, rok jego śmierci. Błahe oskarżenie, na które podobno nie musiał reagować, wyglądające jak próba zastraszenia, dało mu okazję do ujawnienia charakteru i właściwej filozofii życia. Ten przykład zresztą jedyny w swoim rodzaju w dziejach ludzkościi ${ }^{18}$.

Nie przypadkiem patronem wojennego heroizmu stał się sam Sokrates. Trudno też znaleźć lepszy punkt odniesienia dla doktora filozofii z Karpat Wschodnich. W Outoposie znalazłem bardzo osobisty fragment kolejny raz nawiązujący do znanych i ważnych dla Vincenza słów Sokratesa o tym, że „każdy człowiek pragnie dobra”:

Czyje życie chciałoby uzyskać sens, ten winien wszystkie niemal inne słowa zakorzenić $w$ tych dwu lub trzech słowach, aby ciagnęły $\mathrm{z}$ nich soki, aby jednak nie przeciążały korzeni, aby dawały im swoje soki i wymieniały się nimi. Które są te dwa lub trzy słowa? Dobro - trwałość - korzyśśc ${ }^{19}$.

Tuż przed wyjazdem na Węgry otrzymałem od pani Bożenny Rotman, Polki pracującej w jerozolimskim Instytucie Yad Vashem, kopie dwóch listów, przechowywanych w teczce Stanisława VincenzaSprawiedliwego Wśród Narodów Świata.

18 Stanisław Vincenz, Pole Bobrowe, w: Z perspektywy podróży, Kraków 1980, s. 360.

19 Stanisław Vincenz, Outopos..., dz. cyt., s. 165. 
Pierwszy list został napisany przez Adę Neuspiel, szwagierkę inżyniera Martina Hajdu, i złożony w Yad Vashem jako świadectwo heroicznej postawy Leny, Ireny i Stanisława Vincenzów, którzy późnym latem 1942 r. współorganizowali (wraz z małżeństwem Hajdu) ucieczkę małżeństwa Ady i dra Emila Neuspielów z Austrii na Węgry przez zieloną granicę. Miało to miejsce 5 września 1942 r. Vincenz po udanym przerzucie (przekupiono austriackiego bauera mieszkającego w strefie przygranicznej) zabrał Neuspielów do swojego domku w Verőce i dzielił się z nimi swoimi kartkami żywnościowymi i zapomogą uchodźcy. Zaświadczył także przed miejscowymi władzami oraz w MSW w Budapeszcie, że nowo przybyli są krewnymi z Polski wyznania rzymskokatolickiego. Następnie, używając swoich znajomości, zorganizował przeprowadzkę Neuspielów do miasteczka Felsőgöd, bliżej Budapesztu, gdzie zamieszkali w pożydowskim domu, którym opiekowała się zaufana węgierska gospodyni. Pani Neuspiel była przed wojną thumaczem przysięgłym w sądzie w Wiedniu. W nowej sytuacji zarabiała na życie lekcjami języka niemieckiego. Po wkroczeniu Niemców na Węgry Vincenz przedstawiał wszędzie Neuspielów jako uciekinierów katolików. Podobnie uczynił w klasztorze pijarów w Esztergomie. Dzięki takiej legitymizacji uciekinierzy z Wiednia dotrwali do końca wojny i powrócili do domu.

Autorem drugiego listu, adresowanego do ambasadora Izraela w Wiedniu, jest Danek Gertner, jeden z dwóch synów karczmarza Lejzora Gertnera w Żabiu, uwiecznionego w Na wysokiej połoninie jako arendarz Etyk. Autorka biografii Vincenza napisała:

Obaj przedostali się na Węgry i odnaleźli tam przyjaciela swego ojca, Stanisława Vincenza [było to w grudniu 1942 r. - T. M.]. Ten udał się z nimi wprost do Jozefa Antalla i poprosił o wystawienie im dokumentów stwierdzających polską narodowość oraz wyznanie katolickie. Otrzymali dokumenty na nazwisko Żaba i zostali oddani do szkoły zawodowej. Później zajęli się handlem $[\ldots]^{20}$.

20 Mirosława Ołdakowska-Kuflowa, Stanisław Vincenz. Biografia, dz. cyt., s. 226. 
Danek Gertner potwierdził te fakty w swoim liście. Opisał także losy jeszcze jednej osoby, którą autor huculskiej tetralogii darzył szczególną sympatią. W 1943 r. Vincenz wyrobił stosowne dokumenty młodemu chasydowi z Rachowa o nazwisku Friedmann, wychowankowi rabina Rokacha w Bełzie. Przetrwał on całą okupację pod nazwiskiem Stanisław Zięba, a po wkroczeniu Niemców na Węgry ukrywał się przez pewien czas w Veröce w domku Vincenzów, który znał z wcześniejszych wizyt. Po latach pisarz wspominał go bardzo ciepło:

Nie opuszczała go naiwna ufność w hierarchię duchową że światem kierują siły duchowe i że „ci inni” dobrze o tym wiedza. Wobec zarzutów, że ci inni mają przynajmniej na razie coś do gadania, twarz jego przybierała uśmiech dyskretnej ironii, czy raczej zakłopotanej a przebaczającej wiedzy. Był śliczny, jego szafirowe oczy gorzały życzliwością chętną i dzielna. Mimo lat z górą dwudziestu, ruchy były chyże i zgrabne jak u wyrostka. Wyskakiwał i wskakiwał do pociagu i do tramwaju w biegu, i może ta zgrabność już przez wrażenie niewymuszonej swobody, ocaliła go od licznych obław policyjnych skuteczniej jeszcze niż legitymacja ,aryjska"21.

Skończyła się wojna. Vincenzowie spędzają święta Bożego Narodzenia - ostatnie na ziemi wegierskiej - w 1945 r. Pisarz spod Czarnohory zapamiętał je i uwiecznił w przywoływanym eseju z roku 1952:

Nie mogliśmy się ruszyć, nie był to czas wesoły, nie wiedzieliśmy co się dzieje z naszymi najbliższymi rozsianymi po świecie; wobec ciągłego spadku waluty sytuacja pieniężna i żywnościowa stała się bardzo trudna. Dla nabycia w drodze wymiany kukurydzy, thuszczu i opału, trzeba było sięgać do zapasów garderoby uchodźczej. Dobrze przynajmniej, że na wigilię dom nad Dunajem był jako tako ogrzany, że był barszcz z chlebem, kluski z makiem i choinka ze świeczkami. Wieczorem usłyszeliśmy pukanie do drzwi i nieoczekiwanie ukazał się w nich Zięba obładowany plecakiem. [...] Przywiózł nam na wigilię zapasy żywnościo-

${ }^{21}$ Stanisław Vincenz, Qu'une l'arme dans l'ocean, w: Po stronie pamięci, Paryż 1965, s. 205. 
we i dawno niewidziane smakołyki, w różnych konserwach. Nasza radość była podwójna, nawet potrójna. Ponieważ w tym roku wigilia przypadła w sobotę, zapytałem Zięby: „W sobotę koleją i z plecakiem? Taki chasyd z pana?”. Zięba uśmiechnął się: „Właśnie tak. Chasyd ma nie zapominać o przyjaciołach, ma ich cieszyć. Te drobiazgi po to, aby wam było weselej na święta ${ }^{22}$.

Rok wcześniej, wiosną 1944 r. w domku Vincenzów ukrywał się także Andrzej Stawar (1900-1961), przedwojenny komunista, a na emigracji węgierskiej redaktor naczelny „Tygodnika Polskiego”, później współpracownik paryskiej „Kultury”.

Na tych kilku przykładach, a należy także pamiętać o akcji ratowania żydowskich dzieci w katolickich przytułkach, np. w pobliskim Vácu oraz w Rákóczifalvie, widać, ile dobra dokonywało się w Verőce zarówno za sprawą aktywności i odwagi Vincenzów, jak i pozostałych Polaków i ludności węgierskiej.

Autor Dialogów z Sowietami jest bardzo skromny i powściagliwy, wiele kwestii celowo przemilcza i nie zatrzymuje się nad własnym losem. Przypadków niegodnego zachowania innych nie zna lub je pomija, natomiast z całym przekonaniem pisze o solidaryzmie dobrych ludzi - „w naszym sąsiedztwie ukrywały się dwie Żydówki węgierskie"23.

Spacerując uliczkami skromnej i cichej miejscowości (niewiele się w niej buduje, a całe życie skupia się wokół małego supermarketu), próbowałem sobie wyobrazić, gdzie Vincenzowie dokładnie mieszkali, gdzie ukrywali uciekinierów, gdzie pisali itd. Więcej tu pytań, tajemnic, ukrytych nazwisk, nieznanych epizodów niż odpowiedzi. Jak to wszystko pozbierać w całość i zrekonstruować dla potomnych? Vincenz zanotował, że mieszkali „,daleko na końcu wsi za górą i pod lasem"24, a więc nie w centrum i nie nad Dunajem. W innym miejscu zapisał: ,[...] główny trakt, którym przechodziły [oddziały wojskowe

\footnotetext{
Tamże, s. 206-207.

Stanisław Vincenz, Dialogi..., dz. cyt., s. 186.

Tamże, s. 185.
} 
- T. M.] biegł nad samym Dunajem, jakie półtora kilometra od nas"25. Zresztą o rzece w Dialogach z Sowietami pisze bardzo mało.

\section{Świat jest mały}

O godzinie 17 w miasteczku wypogodziło się i ukazało się słońce. Przed wysoką, kutą bramą Muzeum Gézy Gorki stanął samochód, z którego wysiadł w towarzystwie żony dystyngowany starszy pan z siwą bródką. Wymieniliśmy powitalne uprzejmości i zaczęliśmy rozmawiać po angielsku. Pan László Erős-Znorovszky jest dziennikarzem i pracował m.in. w radiu budapeszteńskim, a w Verőce mieszka od ponad 50 lat przy Árpád utca 74. Jego dziadek pochodził z Galicji i nazywał się Mocny. Zadałem mu pytanie wprost: „Gdzie przez prawie sześć lat mieszkał Vincenz?”. „Tego nikt nie wie - odpowiedział i po chwili dodał - w 2007 r. prof. Csaba Kiss z Budapesztu zebrał najstarszych mieszkańców miasteczka i próbował z nimi ustalić, gdzie mógł być dom Vincenza. Bezskutecznie. Natomiast wiadomo, gdzie mieszkał przez pewien czas, gdy wkroczyli tutaj Niemcy i Rosjanie...". Pan László przerwał wypowiedź i zaprosił mnie i towarzyszące mi osoby do swojego domu nad Dunajem. Z holu przeszliśmy przez gabinet z książkami na półkach po sam sufit do małego ogródka na skarpie naddunajskiej, z której roztaczał się przepiękny widok na Wyszehrad i wzgórza naprzeciwko, z których podczas okupacji Niemcy ostrzeliwali miasteczko. Dziennikarz wykonał kilka telefonów i po chwili pojechaliśmy na sąsiednią ulicę, do parterowego, żółtego domu na Rákóczi utca 14. „Tu mieszkał Vincenz - powiedział triumfalnym tonem - i obecni gospodarze nas oczekują".

Właściciele domu (posesja składa się z trzech budyneczków połączonych ze sobą na planie litery „L”) - pogodne, starsze małżeństwo - zaprosili nas do słonecznej kuchni i przy lampce domowego wina wspominali czas wojny w Verőce, a pan László tłumaczył na angielski. Pani Illes Gyotgyne, która na początku wojny miała 12 lat, wspominała, że jej matka Vilma Varga udzielała schronienia uchodźcom od 1939 r. Janina Lesiecka tak zapamiętała pobyt w tym domu:

25 Tamże, s. 209. 
Po miesiącu przeniosłam się do Nogradveroce. Sławna ta miejscowość zasłużyła sobie na specjalną wdzięczność Polaków, bo trudno znaleźć by było chyba drugie takie miejsce na Węgrzech, gdzie by tak bardzo lubiano Polaków. Wraz z dwoma paniami dostałam kwaterę u pewnej młodej wdowy. Nazywała się Vilma i była rodowitą Węgierką. Dużo można by na temat „naszej Vilmy” napisać. - Pokochała nas jak siostry rodzone, a ponieważ mówiła tylko po węgiersku, więc szybko trzeba się było tego języka nauczyć, aby móc jej wytłumaczyć to, co ją interesowało. A interesowało ją wszystko, co nas dotyczyło. Płakała wraz z nami nad losem naszych najbliższych i cieszyła się wraz z nami z jakiegoś cudownego odnalezienia kogoś z rodziny. Trudno mi opisywać poszczególne objawy życzliwości z jej strony - było ich zbyt wiele. W każdym razie wiedzieliśmy zawsze, że w każdym wypadku na jej pomoc liczyć można. I rzeczywiście, często pomagała nam i naszym znajomym w chwilach, kiedy to od niej wymagało wiele dobrej woli. Zresztą to oddanie Polakom cechowało prawie wszystkich nogradveroczan ${ }^{26}$.

Węgrom utkwili w pamięci polscy żołnierze i oficerowie, którzy ze względu na liberalne zasady internowania na terytorium ich państwa, kwaterowali w wielu domostwach we wsi. Pani Illes dużo mówiła o inżynierze Gadomskim, który przyjaźnił się z Vincenzem i o samym pisarzu, który w końcu u nich zamieszkał, kiedy Niemcy zaczęli ostrzeliwać okolice z prawego brzegu Dunaju. Bard spod Czarnohory w Dialogach z Sowietami często wspomina wiele nocy spędzonych w piwnicach:

W okresie najbardziej burzliwym, kiedy front był blisko i kiedy wraz z wieloma sąsiadami zamieszkaliśmy w piwnicy ${ }^{27}$.

Zamieszkanie w pobliskiej piwnicy, a zapasowo w pokoiku nad piwnicą sprawiało, że do naszego własnego mieszkania wykwaterowywały się coraz to nowe oddziały, czasami sztaby ${ }^{28}$.

${ }^{26}$ Helena i Tibor Csorba, Losy młodzieży polskiej na Wegrzech w latach II wojny światowej, Warszawa 1981, s. 197-198.

27 Tamże, s. 225.

28 Tamże, s. 229. 
Nazywał się Konstantin [Vincenz mówi o pewnym sowieckim żołnierzu - T. M.], a poznałem go u znajomego węgierskiego muzyka, u którego kwaterował. Chętnie dał się zaprosić i siedział u nas do trzeciej nad ranem, gdy wszyscy w liczbie 7-miu osób już ułożyli się na sen w zbiorowym pokoju nad piwnicąa ${ }^{29}$.

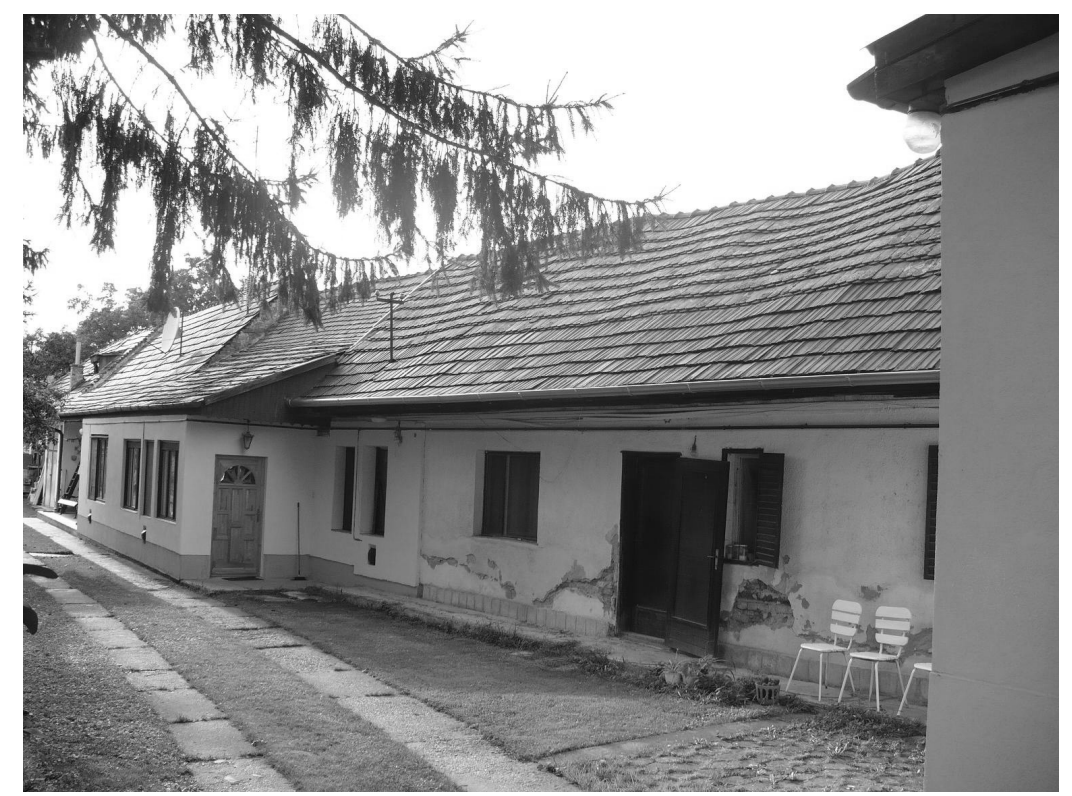

Zabudowania przy Rákóczi utca 14

I jeszcze jeden cytat:

Własne nasze mieszkanie stawało się już coraz bardziej niemożliwe do zamieszkania i nie dla nas tylko, nawet dla kwater, toteż ocaliwszy meble i większość książek zamieszkaliśmy w osiem osób w jednym pokoju nad piwnicą u chłopów sąsiadów. Bateria morska [rosyjscy żołnierze T. M.] zakwaterowała się geśsiej naokoło nas niż którykolwiek oddział dotychczas. Wypełnili nie tylko pokój sypialny gospodarzy i kuchnię zimową, lecz także zadymioną letnią kuchnię tak że nasz pokój był ze 
wszystkich stron otoczony kwaterantami. W letniej kuchni mieszkali i gotowali dla baterii trzej kucharze sami chłopi. Pracowali ciężko, kładli się spać późno, wstawali bardzo wcześnie. Wchodzili do nas nierzadko, to tymi, to owymi drzwiami, to z prawa, to z lewa, a oprócz tego w porach posiłku żołnierze baterii przechodzili galerią pod naszymi oknami czekając tam na napełnienie menażek. Byliśmy gęściej zasypani wojskiem niż kiedykolwiek dotąd ${ }^{30}$. [...] Przeszkadzali mi w czytaniu... ${ }^{31}$.

Po dłuższej rozmowie mąż pani Illes zaprowadził nas w głąb długiego podwórka, gdzie przy środkowej części domostwa znajdowało się wejście do obszernych piwnic. Dwa pomieszczenia były połączone wąskim przejściem, które w razie zagrożenia można było szybko zamurować. Okazało się także, że piwnice sąsiednich gospodarstw były połączone różnymi podziemnymi korytarzami, tworzącymi swoisty labirynt. Po wkroczeniu Rosjan - którzy natychmiast zyskali sławę gwałcicieli i pijaków - część podziemnych pomieszczeń zalano woda, aby lepiej odseparować od wszechobecnych wyzwolicieli różnych ludzi - przede wszystkim zaś młode kobiety, także z sąsiednich miast i z Budapesztu, gdzie nieraz dochodziło do bezkarnych zbiorowych gwałtów. Rosjanie bowiem traktowali Węgrów jako sprzymierzeńców III Rzeszy i uważali, że wszystko im wolno.

Po przejściu frontu, wiosną 1945 r. Vincenzowie powrócili do swojego starego, wynajmowanego domu, a inżynier Gadomski wyjechał z Verőce dopiero w 1948 r. Prawdopodobnie ostatecznie osiadł w USA. Nasi węgierscy gospodarze wspominali z największą atencją majora, lekarza weterynarii, Franciszka Szkutę, który zmarł w Verőce 26 kwietnia 1945 r. w wieku 55 lat. Został pochowany na miejscowym cmentarzu obok grobu rodziców obecnej właścicielki posesji. Pani Illes prosiła, abyśmy nie zapominali o majorze i jak najszybciej powrócili do Verőce, gdyż chce nam pokazać miejsce jego pochówku i uważa, że powinny się na nim znaleźć jakieś polskie emblematy.

W drodze do Budapesztu próbowałem uporządkować wszystkie myśli i wrażenia. Nagle zadzwonił telefon. Była to córka Pawła Ko-

\footnotetext{
30 Tamże, s. 268.

31 Tamże, s. 271.
} 
walinskiego. Po węgiersku, niemiecku i za pomocą kilku polskich słów oświadczyła, że niewiele pamięta, bo jej nieżyjący ojciec nie informował jej o sprawach pana Vincenza, ale jeśli ktoś będzie mógł z nią porozmawiać po węgiersku, to spróbuje sobie coś przypomnieć.

Zadzwoniłem natychmiast do mojej byłej maturzystki, absolwentki hungarystyki i poprosiłem o rozmowę z córką Kowalinskiego. Joasia Korab spisała się znakomicie. Córka Pawła Kowalinskiego potwierdziła następnego dnia, że faktycznie Vincenzowie przez pewien czas mieszkali na Rákóczi utca i zaprosiła nas na rozmowę podczas naszej następnej wizyty na Węgrzech.

Jakże wielu Węgrów pomagało tysiącom Polaków w czasie II wojny światowej, a tak mało wiemy o nich wszystkich. Tyle tajemnic zabrali ze sobą, ale czy naprawdę wszystkie są nie do odkrycia i wyjaśnienia? Do Verőce nad Dunajem należy powrócić i w konkretny, godny sposób uhonorować to miejsce jako pomnik przyjaźni polskowęgierskiej i czynów człowieczeństwa - także za sprawą wielkiej osobowości Stanisława Vincenza i jego rodziny.

Tuż przed wyjazdem na Węgry otrzymałem list od pani Joanny de Vincenz. Małżonka profesora Andrzeja de Vincenza napisała:

Do Węgrów do dziś Mąż odczuwa olbrzymią wdzięczność i szacunek. Zawsze, gdy tylko spotka tu jakiegoś Węgra, obojętne czy będzie to taksówkarz, lekarz czy profesor opowiada mu swą historię rodzinną i wyraża wdzięczność. Tutaj mała - anegdotyczna wręcz - historia z niedalekiej przeszłości. Otóż kilka lat temu we Frankfurcie nad Menem staliśmy na dworcu kolejowym w kolejce do kasy. Przed nami stało dwóch mężczyzn, zawzięcie ze sobą dyskutując. Jakżeż się ucieszyli, kiedy usłyszeli, że między sobą rozmawiamy po polsku! Okazało się, że to Węgrzy (przypuszczalnie Romowie węgierscy), którzy mają żony Polki! Wracali do Warszawy z niezbyt udanych saksów we Francji; koło Frankfurtu zepsuł im się samochód i teraz gorączkowali się, czy starczy im na bilet kolejowy. Mąż bez wahania oczywiście podarował im bilety, opowiadając przy 
okazji o swej wdzięczności dla Węgrów. Długo jeszcze się cieszył z tego niebywale szczęśliwego zbiegu okoliczności.

Pamięć o Stanisławie Vincenzie jest także kultywowana na Węgrzech. Jego wielkim znawcą i admiratorem twórczości jest prof. Csaba G. Kiss. Również w swojej ostatniej książce Lekcja Europy Środ$k_{\text {owej }}{ }^{32}$, opublikowanej w Polsce, poświęcił dużo miejsca i ciepłych słów polskiemu myślicielowi spod Czarnohory.

32 Csaba G. Kiss, Lekcja Europy Środkowej. Eseje i szkice, Kraków 2009. 